\title{
EFEKTIVITAS, EFISIENSI DAN KESEHATAN HUBUNGAN ORGANISASI PELAYANAN DALAM KEPEMIMPINAN KRISTEN
}

\author{
Marde Christian Stenly Mawikere \\ MCSM Ministry \\ Jl. Bahadiang Lingkungan V Aerterang, Malalayang 1 Timur, \\ Malalayang, Manado, Sulawesi Utara 95163 \\ Email: mardestenly@gmail.com
}

\begin{abstract}
Marde Christian Stenly Mawikere, Effectiveness, Efficiency And Health Relationships Service Organization In Christian Leadership. This article reviews the importance of Christian leadership in service organizations. It highlights the aspects that shape and support the effectiveness, efficiency and health of organizational relationships in Christian Leadership. This article emphasizes that in Christian Leadership it begins on the basis of the decision of God's sovereign grace. A Christian leader is a chosen person based on God's own initiative. In the dictionary (leadership) of Christianity, nothing is "accidental". God who chooses, equips, sends a leader at all times, places, situations, conditions, and arenas, including the XXI century full of these challenges. It is God's work that guarantees the certainty of the existence and performance of Christian leaders! The true Christian leader must also realize that God in the Lord Jesus Christ is the only Great Leader. A visionary leader, having a reliable, capable, and God-fearing character/integrity is increasingly needed in the present. Going back to biblical principles is the true source of that.
\end{abstract}

Keywords: Leadership, Leadership, Effective, Efficient, Organization.

\begin{abstract}
ABSTRAK: Marde Christian Stenly Mawikere, Efektivitas, Efisiensi Dan Kesehatan Hubungan Organisasi Pelayanan Dalam Kepemimpinan Kristen. Artikel ini meninjau pentingnya kepemimpinan Kristen dalam organisasi pelayanan. Di dalamnya menyoroti aspek-aspek yang membentuk maupun mendukung efektivitas, efisiensi dan kesehatan hubungan organisasi dalam Kepemimpinan Kristen. Artikel ini memberi penekanan bahwa dalam Kepemimpinan Kristen dimulai berdasarkan keputusan kedaulatan anugerah Allah. Seorang pemimpin Kristen adalah seorang dipilih berdasarkan inisiatif Allah sendiri. Dalam kamus (kepemimpinan) Kristen, tidak ada yang bersifat "kebetulan". Allah yang memilih, memperlengkapi, mengutus seorang pemimpin pada setiap waktu, tempat, situasi, kondisi, dan arena, termasuk pada abad XXI yang penuh dengan tantangan ini. Pekerjaan Allah sajalah yang menjamin kepastian eksistensi dan kinerja pemimpin Kristen! Pemimpin Kristen yang benar harus juga menyadari bahwa Allah di dalam Tuhan Yesus Kristus adalah satu-satunya Pemimpin Yang Agung. Pemimpin yang visioner, memiliki karakter/integritas yang handal, cakap dan takut akan Tuhan semakin dibutuhkan pada masa kini. Kembali kepada prinsip-prinsip Alkitab merupakan sumber yang benar dalam mewujudkan hal tersebut.
\end{abstract}

Kata Kunci: Kepemimpinan, Pemimpin, Efektif, Efisien, Organisasi.

\section{PENDAHULUAN}

Kepemimpinan telah menjadi faktor yang tidak pernah mengenal kadaluarsa di dunia ini. Karena pemimpin-pemimpin adalah isu dari perubahan (Leaders are the Currency of Change). Kepemimpinan tidak hanya terbatas kepada sekelompok kecil negarawan, maupun kepada sejumlah kecil tokoh yang menduduki puncak roda pemerintahan nasional. Kepemimpinan memainkan peranan dalam segala bidang. Para rohaniwan adalah pemimpin da- lam jemaat, para orangtua adalah pemimpin dalam keluarga dan rumah tangga, serta para guru dan dosen adalah pemimpin di sekolah. Demikian pula dengan para eksekutif senior di bidang bisnis dan industri, para hakim, dokter, polisi, politisi, pekerja sosial dan wakil serikat kerja. Semua mereka mengemban tanggung jawab kepemimpinan dalam lingkungan masing-masing. Dalam setiap masyarakat kepemimpinan memiliki bentuk dan rupa yang aneka ragam, baik dalam bidang spiritual maupun pro- 
fan. Ketika disana terdapat pemimpin yang agung, maka sesuatu yang penting akan terjadi (When there is great leader, significant things can happen). Karena itu, tidak dapat dipungkiri bahwa kepemimpinan adalah salah satu faktor yang terus menerus relevan dan signifikan dalam keberhasilan suatu organisasi dalam bentuk apa pun (Arthanto, 2002, p. 1). Kepemimpinan juga menjadi faktor penting dalam kemajuan sebuah gereja (Objantoro, 2017).

Secara sederhana kepemimpinan dapat didefinisikan sebagai keseluruhan sikap, perilaku dan tindakan seorang pemimpin untuk mempengaruhi perilaku orang-orang lain dalam suasana tertentu, sehingga mereka rela melaksanakan tugas dan memikul tanggungjawab untuk mencapai tujuan bersama (Lay, 2001, p. 1). Definisi ini memiliki kemiripan dengan definisi yang diungkapkan oleh Robert J. Clinton dan Yakob Tomatala yang menyatakan bahwa kepemimpinan ialah suatu proses terencana yang dinamis melalui suatu periode waktu dalam situasi yang di dalamnya pemimpin menggunakan perilaku, sarana serta prasarana atau sumber-sumber untuk menggerakkan bawahan untuk melaksanakan tugas kearah tujuan yang menguntungkan pemimpin dan bawahan serta lingkungan sosial di mana mereka hidup (Lihat Tomatala, 2005, p. 29). Dari definisi ini dapat ditegaskan bahwa kepemimpinan menyangkut seni untuk mempengaruhi dan membimbing (influencing and guiding), ketimbang kedudukan dan kuasa (position and power).

Lord Montgomery (dalam Arthanto, 2004, p, 1) mendefinsikan kepemimpinan Kristen sebagai kemampuan dan kehendak untuk mengerahkan orang laki-laki dan perempuan untuk satu tujuan bersama dan watak yang menimbulkan kepercayaan. Sedangkan menurut Tomatala (2002, pp. 12-13), kepemimpinan Kristen adalah suatu proses terencana yang dinamis dalam konteks pelayanan Kristen yang di dalamnya oleh campur tangan Allah, Ia memanggil bagi diri-Nya seorang pemimpin untuk memimpin umat-Nya guna mencapai tujuan Allah bagi serta melalui umat-Nya untuk kejayaan kerajaanNya. Djadi (2009, p. 16) mengungkapkan bahwa ke- pemimpinan merupakan proses pengaruh mempengaruhi antarpribadi dalam situasi tertentu melalui sebuah komunikasi terarah untuk mencapai tujuan yang telah ditetapkan. Dari berapa definisi di atas dapat disimpulkan bahwa kepemimpinan Kristen mengacu kepada sikap dan kemampuan seorang pemimpin di dalam mengikuti panggilan Allah baginya dalam mencapai rencana dan tujuan Allah yang berdaulat di dalam Tuhan Yesus Kristus.

Oleh karena kepemimpinan dalam bidang apa pun menyangkut seorang pemimpin, orangorang yang dipimpin (laki-laki dan perempuan), suasana atau situasi tertentu dan tujuan bersama, maka di dalam kepemimpinan memerlukan faktorfaktor efektivitas, efisiensi dan kesehatan hubungan. Dalam semua bidang dan situasi masa kini semakin terasa kebutuhan yang amat sangat akan pemimpinpemimpin yang mempunyai pandangan ke depan yang lebih tajam, keberanian yang besar dan dedikasi yang tidak tanggung-tanggung (Stott, 2000, p. 459). Apalagi dalam konteks pelayanan, kepemimpinan Kristen yang efektif, efisien dan menjalin hubungan yang sehat menjadi kebutuhan yang mutlak.

\section{METODE}

Artikel ini membahas mengenai "Efektivitas, Efisiensi dan Kesehatan Hubungan Keorganisasian dalam Kepemimpinan Kristen". Penelitian ini dibangun dengan mengadakan telaah teoritis terhadap berbagai literatur yang relevan dengan topik yang dibahas. Riset literatur ini kemudian diolah secara kreatif dan dinamis oleh penulis. Sumbersumber terpercaya dan terpublikasi penulis gunakan dalam penelitian ini. Beberapa sumber literatur yang digunakan berasal dari beberapa penulis yang telah memperoleh pengakuan khususnya terkait kepemimpinan Kristen di Indonesia.

\section{HASIL DAN PEMBAHASAN}

\section{Kepemimpinan Yang Efektif}

Kepemimpinan yang efektif adalah fungsi dari pemimpin dalam hubungannya dengan orang- 
orang yang dipimpin, suasana yang terbina sebagai hasil interaksi antar pribadi dan upaya dalam mencapai tujuan internal maupun eksternal suatu organisasi. Hal ini menyangkut kualitas atau mutu kepemimpinan yang ditentukan oleh pemimpin, orangorang yang dipimpin, suasana atau situasi kepemimpinan maupun tujuan yang ingin dicapai oleh mereka (Lay, 2001, pp. 1-2; Tomatala, 2005, pp. 255-301).

Pemimpin Kristen adalah seorang pribadi yang mempunyai tujuan yang jelas (yaitu tujuan dari Allah) dan memiliki kemampuan untuk mempengaruhi perilaku orang-orang lain sehingga mereka rela memikul tanggung jawab dan melaksanakan tugas-tugas demi mencapai tujuan bersama (Lay, 2001, p. 2). Sebagai pemimpin Kristen, seseorang mengetahui bahwa tugasnya adalah untuk membimbing dan bukan mengatur orang. Ia harus membebaskan diri dari jerat nafsu "kedudukan dan kuasa", dari belenggu "memainkan peranan sebagai Allah yang tidak pernah salah", serta dari keinginan untuk memperalat sesama melalui "peraturan-peraturan yang menguntungkan dirinya sendiri”. Karena itu, hal-hal yang penting bagi seorang pemimpin Kristen yang efektif adalah:

\section{Hubungan Pemimpin Kristen dengan Tuhan}

Seluruh proses kehidupan Kristen (baik keselamatan, pertumbuhan iman maupun "kepemimpinan Kristen") di mulai berdasarkan keputusan kedaulatan anugerah Allah. Seorang pemimpin Kristen adalah seorang dipilih berdasarkan inisiatif Allah sendiri. Apabila Allah yang memulai segala sesuatu, maka Dia pula yang menjamin, memperlengkapi, memampukan dan memakai seorang pemimpin untuk tujuan-tujuan-Nya yang agung. Dalam kamus (kepemimpinan) Kristen, tidak ada yang bersifat "kebetulan". Allah yang memilih, memperlengkapi, mengutus seorang pemimpin pada setiap waktu, tempat, situasi, kondisi, dan arena, termasuk pada abad XXI yang penuh dengan tantangan ini. Pekerjaan Allah sajalah yang menjamin kepastian eksistensi dan kinerja pemimpin Kristen! Konsistensi seorang pemimpin untuk berjalan di dalam Roh Ku- dus ditentukan oleh hubungannya yang konsisten dengan Tuhan. Hubungan yang konsisten ini menolong seorang pemimpin untuk terus memelihara "kasihnya yang mula-mula" (Why. 2:1-7; Yer. 2:23). Hubungan dengan Tuhan yang terpelihara dengan baik akan memungkinkan dia untuk menerima dirinya sendiri, keluarganya, serta orang-orang lain dalam kepemimpinannya (dengan segala kekuatan, kelemahan, aspirasi dan pergumulan yang ada). Lay (2001, p. 2) mengungkapkan bahea pemimpin yang demikian rela menerima setiap orang dalam lingkup kepemimpinannya sebagaimana mereka ada dan berusaha untuk mengembangkan potensi mereka (Ef. 4:11-15). Hal inilah yang dinamakan "hati seorang pemimpin" (Ams. 4:23).

Pemimpin Kristen yang benar harus juga menyadari bahwa Allah di dalam Tuhan Yesus Kristus adalah satu-satunya Pemimpin Yang Agung (Mat. 23:10). Karena Allah sendiri sebagai pemimpin agung telah menciptakan alam semesta dan segala isinya dalam keteraturan, maka Ia juga menetapkan perlu adanya kepemimpinan dalam alam semesta yang menata, menggerakkan, mengelola dan mengatur segela sesuatu untuk tujuan kekal-Nya. Manusia yang diciptakan dalam gambar Allah, telah ditentukan sebagai pemimpin-pemimpin. Berangkat dari pemahaman tersebut, maka kepemimpinan merupakan bagian drai teologi dengan landasannya yang kokoh dalam berita Alkitab.Alkitab memiliki kekayaan yang luar biasa dalam menjelaskan selukbeluk kepemimpinan, mulai dari profil seorang pemimpin, proses menjadi pemimpin sampai kepada suksesi kepemimpinan. Kebutuhan akan seorang pemimpin sejati secara holistik dalam segala sektor semakin urgen. Pemimpin yang visioner, memiliki karakter/integritas yang handal, cakap dan takut akan Tuhan semakin dibutuhkan pada masa kini. Kembali kepada prinsip-prinsip Alkitab merupakan sumber yang benar dalam mewujudkan hal tersebut.

Beban dan tanggungjawab yang berat selalu berada di pundak seorang pemimpin. Ia harus senantiasa mengandalkan Tuhan serta memohon kekuatan dan kemampuan dari-Nya dalam melaksanakan tu- 
gas-tugas yang berat tersebut. Disamping itu seorang pemimpin yang menerima kapasitas dari Allah perlu memakai kapasitas tersebut dalam menyusun rencana kerja dan melaksanakan dengan pertolongan Tuhan. Dengan kemampuan dari Tuhan, maka seorang pemimpin akan memiliki motivasi dan sikap yang selalu didorong untuk maju dan pantang menyerah. Dia juga memotivasi para bawahannya untuk memiliki sikap dan perilaku yang rindu untuk meraih keberhasilan dalam pertolongan Tuhan.

Pemimpin Kristen yang baik adalah seorang pemimpin yang memiliki hubungan pribadi dengan Tuhan Yesus. Tidak terdapat pemimpin yang ideal dan sempurna di dunia ini. Namun terdapat pemimpin yang "beriman" dan bukan sekedar "beragama". Pemimpin tersebut telah mengalami kasih, pengampunan dan keselamatan dari Tuhan Yesus Kristus. Pemimpin yang demikian akan menjadi "gembala" yang senantiasa adil, bijak dan bajik. Ia akan mengayomi, membela dan menyejukkan, seperti Kristus, Sang Juruselamat!

\section{Pertumbuhan Rohani Pemimpin Kristen Secara Pribadi}

Kematangan pribadi seorang pemimpin hanya dihasilkan melalui pertumbuhan (growth) yang terus menerus. Pemimpin-pemimpin Kristen akan tetap mengalami pertumbuhan apabila sikap hidupnya (attitude) memang memenuhi syarat-syarat pertumbuhan. Disiplin diri misalnya, bukan suatu mode atau metode melainkan harus menjadi bagian integral dari kehidupannya. Dalam konteks kepemimpinan Kristen, kematangan pribadi senantiasa ditandai dengan kehadiran beberapa komponen antara lain menyangkut pertumbuhan Karakter pemimpin Kristen.

Kemampuan seorang pemimpin untuk mempengaruhi orang lain tidak terletak pada wewenang formal yang dimiliki, tetapi ditentukan oleh karakternya. Istilah "karakter" berarti kualitas moral yang signifikan dalam kepribadian seseorang yang menyebabkannya mempunyai pengaruh yang positif dalam lingkungannya (Lay, 2001, p. 2). Efektivitas kepemimpinan tidak tergantung pada pengalaman kerja, tingkatan (degree) dan latar belakang pendidikannya, melainkan pada pembaharuan karakter seorang pemimpin secara terus menerus. Fred Smith (seperti dikutip oleh Susabda, 1990, p. 44) dengan tepat menegaskan bahwa kepemimpinan yang efektif bermula dari karakter. Apabila para pemimpin jatuh, itu lebih sering disebabkan oleh karena adanya cacat pada karakter ketimbang karena kurangnya kompetensi. Semakin besar tanggung jawab kepemimpinan, semakin berat beban dan tanggung jawab seorang pemimpin maka semakin dibutuhkan karakter yang kuat. Bila tidak maka ia akan "patah" di tengah jalan. Itulah sebabnya siapa diri kita lebih penting daripada apa yang kita lakukan. Kepemimpinan sejati adalah karakter pemimpin itu sendiri dan daya tahan/kesinambungan kepemimpinan diuji oleh kekuatan karakternya (Arthanto, 2002, p. 3).

Menurut Efesus 4:2, karakter Kristiani yang penting adalah: rendah hati, lemah lembut, sabar, dan saling membantu. Keempat karakter ini bertumpu pada karakter dasar yaitu kasih (agape). Dalam Galatia 5:22-23, kasih adalah buah Roh Kudus yang dinyatakan dalam delapan dimensi/sifat, yaitu: sukacita, damai sejahtera, kesabaran, kemurahan, kebaikan, kesetiaan, kelemahlembutan, penguasaan diri. Karena karakter kasih dan semua bentuk ekspresinya tersebut adalah buah Roh Kudus, maka tidak ada jalan lain kecuali seorang pemimpin haruslah seorang yang dipenuhi oleh Roh Kudus, dipimpin oleh Roh Kudus, dan berjalan di dalam Roh Kudus (Lay, 2001, p. 2). Allah memanggil para pemimpin dan mempercayakan sesuatu yang besar untuk dilaksanakan oleh pemimpin. Di dalamnya menyangkut pekerjaan Allah, orang-orang yang dipimpin, pelayanan, sumber-sumber dan kapasitas/kemampuan yang diberikan oleh Allah sebagai kepercayaan-Nya. Karena itu seorang pemimpin yang dapat dipercaya adalah mereka yang bertanggungjawab penuh atas apa yang dipercayakan oleh Allah kepadanya. Seorang pemimpin memiliki kebutuhan utama untuk terus bertumbuh dalam pribadi dan kepemimpinannya bersama dengan para pengikutnya. 
Pertumbuhan atau perkembangan pemimpin mutlak, baik kepribadiannya maupun kerohaniannya serta kemampuannya dalam melaksanakan tugas-tugasnya.

\section{Pemimpin Dengan Jiwa Seorang Pelayan}

Tuhan Yesus Kristus adalah teladan yang agung mengenai pemimpin yang melayani. Dia telah membuktikan bahwa Dia datang bukan untuk dilayani, melainkan untuk melayani dan memberikan nyawa-Nya untuk menjadi tebusan bagi banyak orang (Mrk. 10:45). Peristiwa salib merupakan bukti yang nyata akan klimaks keberadaan Tuhan Yesus sebagai pemimpin pelayan. Robert K. Greenleaf, (dalam Susabda, 1990, p. 45) seorang pakar riset dan pendidikan manajemen profan telah menegaskan hal yang sama mengenai servanthood ini: "Pemimpin pelayan adalah pertama-tama seorang pelayan yang dimulai dengan suatu perasaan alami bahwa seseorang ingin melayani, melayani terlebih dahulu. Kemudian barulah datang pilihan yang diputuskan dengan sadar yang menginspirasikan seseorang untuk memimpin. Orang ini berbeda sekali dengan dia yang pertama-tama adalah seorang pemimpin. Orang yang duluan menjadi pemimpin dan yang duluan menjadi pelayan adalah dua tipe yang berbeda secara ekstrim." Kenneth Blanchard juga menyatakan hal yang sama ketika ia menyebutkan mengenai tiga aspek kepemimpinan, yaitu hati yang melayani (servant heart), kepala atau pikiran yang melayani (servant head) dan tangan yang melayani (servant hands). (Anonimus, t.t., p. 1).

Dalam prinsip Kerajaan Allah pelayanan bu-

kan batu loncatan untuk keagungan; melayani itu sendiri adalah keagungan, satu-satunya jenis keagungan yang otentik. Kristus yang adalah Tuhan atas semua manusia, Ia telah menjadi pelayan bagi semua. Dengan mengikatkan kain penyeka kaki dipinggang-Nya, Ia bersimpuh untuk membasuh kaki para rasul. Kini Ia meminta kita melakukan yang sama seperti yang dilakukan-Nya, untuk mengenakan jubah kerendahan hati dan saling melayani dalam kasih (Stott, 2000, pp. 472-476). Jiwa seorang pelayan merupakan komponen yang sangat penting dalam pertumbuhan pribadi pemimpin Kristen. Di luar konteks servanthood, kepemimpinan dan manajemen gereja tidak akan menghasilkan pertumbuhan dari orang-orang yang dipimpin. Pemimpinpemimpin yang berkarisma hanya akan menghasilkan pengikut-pengikut buta, dan manajemen yang baik hanya akan membuahkan robot-robot pelayan organisasi (Susabda, 1990, p. 45).

\section{Integritas Sebagai Nilai Kehidupan}

Istilah "integritas" memang sulit diterjemahkan ke dalam bahasa Indonesia karena artinya merupakan kesatuan dari kejujuran, harga diri, dan kualitas pribadi yang dapat dipercayai (kredibilitas). Integritas menunjuk mengenai keadaan menjadi lengkap, merupakan kesatuan. Bila seorang pemimpin mempunyai integritas, perkataan dan perbuatannya sesuai, seorang pemimpin adalah diri pemimpin, tidak peduli dimana dirinya dan bersama siapa. Seorang pemimpin yang mempunyai integritas tidak membagi loyalitas (sikap mendua), dan tidak berpura-pura (munafik). Seorang pemimpin yang memiliki integritas adalah orang yang "utuh", mereka bisa diidentifikasi dengan kesatuan pikirannya. Seorang yang memiliki integritas tidak memiliki apapun untuk disembunyikan, dan tidak punya apapun yang ditakuti. Kehidupan mereka seperti kitab yang terbuka. Dengan kata lain, seorang yang memiliki integritas adalah orang yang menetapkan sistem norma untuk menilai semua kehidupan. Integritas bukanlah apa yang pemimpin lakukan, melainkan siapa pemimpin tersebut. Setiap manusia menghadapi keinginan-keinginan yang saling bertentangan. Dalam hal ini, integritas merupakan faktor yang akan menentukan kemenangan. Integritas akan menetapkan aturan dasar untuk memecahkan masalah tersebut. Mengapa seorang pemimpin membutuhkan integritas? Pertama, integritas pada diri pemimpin akan melahirkan kepercayaan pada para pengikut. Kedua, integritas mempengaruhi efektivitas pelayanan seorang pemimpin. Ketiga, integritas akan memudahkan meningkatkan standar tanggung jawab kepemimpinan. Pemimpin harus hidup dengan standar 
lebih tinggi daripada pengikutnya. Dalam konsep dunia, seorang pemimpin justru mendapatkan hak lebih banyak mengiringi tanggung jawab yang semakin berat. Dalam pelayanan Kristen yang terjadi adalah sebaliknya. Semakin tinggi tingkat kepemimpinan seseorang, justru ia semakin melepaskan haknya, sementara tanggung jawabnya meningkat. $\mathrm{Ke}$ empat, integritas menghasilkan reputasi yang kuat bagi seorang pemimpin, bukan hanya citra diri semata. Citra diri adalah pandangan orang terhadap seorang pemimpin, sedangkan integritas adalah siapa diri kita sesungguhnya. (Arthanto, 2004, pp. 5-6).

Pemimpin yang memiliki integritas tidak akan memakai cara-cara dunia untuk mencapai tujuan organisasi. Ia tidak akan menyuap, ia tidak akan memutar balikkan kebenaran untuk tujuan apapun juga. Ia berani membayar harga, dimusuhi, tidak disukai, kehilangan popularitas, dan kesepian demi untuk kebenaran yang dipercayainya. Ia tidak merasa rugi kehilangan waktu dan tertundanya suatu rencana demi kepentingan pertumbuhan pribadi dari orang-orang yang dipimpinnya. Ia tidak merasa malu untuk mengakui kesalahan dan meminta maaf. Keterbukaan dan kejujurannya ditempatkan dalam ikatan "kasih agape" (1 Kor. 13), sehingga keduanya selalu saling membangun (Susabda, 1990, p. 46). Pada akhirnya seorang pemimpin yang memiliki integritas akan tercermin di dalam kehidupannya yang rendah hati, bukan hamba uang, loyal dan taat pada pimpinan di atasnya, dapat bekerja sama dengan orang lain, mengasihi Tuhan dan sesama, memelihara kekudusan hidup, memiliki sikap yang militan, disiplin, tekun, dan bertanggungjawab.

Integritas juga berkaitan dengan motivasi seorang pemimpin. Motivasi adalah penyebab dari segala tindakan manusia. Motivasi merupakan alasan-alasan yang menggerakkan manusia untuk melakukan sesuatu. Motivasi tidak terlihat, sesuatu yang tersembunyi namun sangat menentukan "hidup" dan "matinya" manusia. Motivasi yang murni akan mendorong seorang pemimpin yang berkualitas sekalipun di tengah-tengah tantangan, penderitaan, kekurangan dan berbagai ujian. Motivasi yang tidak mur- ni akan membuat pemimpin tidak berkualitas, tetapi hanya melayani diri sendiri. Ambisi dalam diri seseorang (termasuk pemimpin), bukanlah sesuatu yang menakutkan. Ambisi akan terwujud, benar-tidaknya melalui "murni atau tidak murninya" sebuah motivasi.

\section{Kepedulian Sebagai Hakikat Hidup}

Tuhan Yesus dengan jelas sekali mengatakan, "perbuatlah apa yang kamu suka orang lain perbuat kepadamu," (Mat. 7:12). Kata-kata ini mengandung pengertian yang begitu mendalam yang hanya dapat dipahami oleh mereka yang mempunyai kematangan pribadi. Tanpa kematangan pribadi, pemahaman, penghayatan dan penerapan dari katakata tersebut selalu "bias" dan berat sebelah. Kematangan pribadi selalu ditandai dengan kepekaan terhadap perasaan sesama. Kasih yang sejati tidak pernah lahir dari pemilihan pribadi atas mana yang harus lebih dikasihi. Seorang pemimpin Kristen bukanlah seorang manajer atau pemimpin rohani. Panggilan dan tugasnya yang utama bukanlah mengorganisir orang-orang untuk mencapai sasaran dan target organisasi. Karena dibandingkan dengan kepentingan "pertumbuhan" dari setiap individu yang dipimpinnya, maka rencana, sasaran dan target organisasi (bagaimanapun baiknya) menjadi sekunder.

Kepedulian seorang pemimpin terhadap sesama berkaitan dengan sikap rendah hati (humility). Kehidupan seorang pemimpin yang rendah hati dibuktikan dengan sikap dan perilaku yang tidak menampilkan diri atau orang yang senantiasa berkarya di belakang layar. Pemimpin yang demikian adalah pemimpin yang senantiasa berbahagia karena jaminan dan penyertaan dari Allah serta memiliki karakter yang menghadapi segala tantangan, jujur dalam segala hal serta tidak kompromi dengan perkaraperkara yang jahat. Pemimpin yang rendah hati adalah pemimpin bersedia untuk namanya tidak dikenal atau tidak di sebut-sebut namanya. Pemimpin-pemimpin tersebut bersedia untuk tidak menjadi favorit dan mendapatkan pujian dari masyarakat umum. Kehidupan dan pelayanan mereka hanya berdasar- 
kan pengabdian semata. Allah menghendaki para pemimpin untuk hidup bahagia dan berkenan memakai para pemimpin untuk membuat orang lain hidup berbahagia pula, sekalipun bukan bergantung pada suasana maupun keadaan lingkungan. Pujian yang berlebihan kerapkali menjadi jerat seorang pemimpin. Akan tetapi pemimpin juga sering menghadapi fitnah dan cercaan yang pedas. Allah yang telah menetapkan seorang pemimpin akan memberi pertolongan pada waktunya sehingga pemimpin tersebut akan tetap tegar.

Pemimpin yang rendah hati dan mengabdi sebagai hamba Tuhan akan dipakai oleh Allah dalam membangunkan, membaharui, dan menyegarkan umat Allah yang pada gilirannya akan memobilisasi umat Allah untu melayani jiwa-jiwa yang terhilang, dibawa pada Tuhan Yesus Kristus, Sang Penebus dan Juruselamat. Pemimpin adalah alat yang dapat dipakai Tuhan untuk menyatakan kemuliaan-Nya bagi umat-Nya dan orang-orang berdosa.

\section{Teladan Kehidupan}

Alkitab kerapkali menyaksikan bahwa salah satu keunikan dari kepemimpinan Kristen adalah menjadi model yang dapat diteladani (Yoh. 13:15; Flp. 3:17; 1 Tes. 1:7; 2 Tes. 3:17; 1 Tim. 4:12; Tit. 2:7; 1 Pet. 5:3b). Diteladani artinya dicontoh sikap dan perilakunya yang baik. Meskipun demikian dalam konteks kepemimpinan Kristen, kata "diteladani” memiliki makna yang lebih luas. "Model yang dapat diteladani" dapat berarti: Pertama, ajaran dan perkataannya menghasilkan perubahan hidup orang yang mendengar (Rm. 10:17). Semakin jelas konsep kebenaran yang diajarkan, semakin mudah pendengar menangkap dan mentransfer kebenaran itu dalam perbuatan. Dengan demikian dapat disimpulkan bahwa seorang pemimpin Kristen yang dapat diteladani adalah pemimpin yang mampu menghadirkan kebenaran firman yang ia beritakan dalam konsepkonsep yang jelas dan mudah dicerna. Kedua, praktik hidup yang konsisten dengan apa yang diajarkannya merupakan kekuatan yang mendorong orang lain untuk meneladani dia (1 Tim. 4:12). Pemimpin
Kristen yang hidupnya konsisten dengan apa yang diajarkan dengan sendirinya menjadi model yang diteladani. Tuhan Yesus, Guru yang Agung adalah contoh yang paling sempurna. Edisi Injil yang paling efektif sebetulnya melekat di bawah kulit manusia. Efektivitas Yesus sebagai seorang guru adalah ketika Ia adalah berita itu sendiri. Kesatuan antara kata dan perbuatan dalam hidup seorang pemimpin akan menghasilkan proses "indentifikasi" dalam diri orang-orang lain. Dari sudut "pola tingkah laku", orang-orang tersebut bertingkah laku sama seperti si pemimpin; dari sudut "motivasi", mereka terdorong untuk mencontoh apa saja yang dilakukan si pemimpin; dan kedua hal ini adalah proses yang biasanya sedikit demi sedikit mengubah hidup mereka yang dipimpin. Identifikasi hanya akan terjadi apabil secara konsisten pemimpin Kristen mempraktikkan apa yang ia ajarkan. Ketiga, otentisitas atau keaslian/ kemurnian yang dimanifestasikan secara nyata memiliki dampak yang sangat kuat dalam pertumbuhan pribadi sesamanya. Seorang pemimpin Kristen tidak perlu menjadi "seorang lain", "bermain sandiwara" atau "memakai topeng pendeta yang ideal", supaya diteladani pengikutnya. Karena apa yang akan diteladani adalah "bagaimana Allah hadir dan bekerja secara unik dalam kehidupannya sendiri”.

Kerapkali kebahagiaan para pemimpin dan bawahannya apabila sasaran mereka telah tercapai. Luapan kebahagiaan muncul karena adanya jaminan dari Allah yang memberi kebahagiaan. Dalam menghadapi berbagai persoalan, pemimpin yang baik akan sabar terhadap segala rintangan-rintangan besar, jujur dalam segala hal serta tidak kompromi dengan sesuatu yang tidak benar. Pemimpin tersebut adalah pemimpin yang memiliki sikap dan perilaku yang menjadi teladan bagi orang-orang yang dalam kebingungan atau kesukaran. Pemimpin yang demikian akan membuat para pengikutnya bahagia dan menjadi model yang dapat diikuti oleh setiap pengikut-pengikutnya, sehingga mereka akan berhasil untuk mencapai dan meraih sasaran yang dituju.

Pada akhirnya menjadi model yang dapat diteladani benar-benar merupakan tantangan kepe- 
mimpinan Kristen sepanjang zaman. Menjadi model bukanlah sesuatu yang dapat dipelajari melalui buku teks, kuliah-kuliah dan kegiatan-kegiatan rohani. Lamanya seseorang belajar di sekolah teologi, tinggi dan banyaknya gelar teologi yang ia miliki, bahkan bakat-bakat berkhotbah dan mengajar itu sendiri tidak dapat menjamin seorang pemimpin untuk menjadi model yang diteladani. Ia harus mulai dari kelahiran baru, secara konsisten terus menerus berjalan dalam pimpinan Roh Kudus dan pertumbuhan pribadinya tidak boleh berhenti. Ia harus memiliki jiwa seorang "murid" yang abadi (Yes. 50:4-6). (Susabda, 1990, pp. 52-54).

\section{Pembelajar Yang Abadi}

Belajar adalah proses seumur hidup. Belajar menunjukkan sikap "miskin di hadapan Tuhan", sikap lapar dan haus akan kebenaran dan sikap yang ingin maju. Yang penting dalam hal ini adalah keseimbangan dalam belajar, baik melalui pengalaman hidup dengan Tuhan dan sesama maupun memperlengkapi diri dengan pengetahuan (knowledge) dan ketrampilan (skill). Belajar bisa kepada orang yang lebih tua, pemimpin, guru; bisa juga dengan sesama rekan dalam pelayanan, bahkan bisa dengan orang yang dipimpin atau orang yang lebih muda dari si pemimpin (Arthanto, 2004, p. 5). Untuk menghadapi tantangan dalam kepemimpinan Kristen pada zaman ini, pemimpin Kristen harus memiliki jiwa "murid yang abadi". Artinya, dia harus menyadari bahwa meskipun ia bertumbuh (baik secara rohani, karakter, pengetahuan dan ketrampilan), ia tidak pernah berhenti untuk menjadi seorang murid. Ia tidak boleh "berhenti untuk bertumbuh" atau peranannya dalam kepemimpinan Kristen akan tidak efektif atau akan mati.

Yesaya 50:4-6 berbicara mengenai "pemimpin dan pengajar" yang juga adalah seorang murid. Hanya "lidah seorang murid, yang bisa memberi semangat baru kepada orang-orang yang letih lesu" (ayat 4); hanya telingan seorang murid, yang peka untuk mendengar (ayat 4b); dan hanya sikap seorang murid yang rela mendengar apa saja yang Tuhan ajarkan (ayat 5). Sikap (attitude) yang seperti inilah yang memungkinkan seorang pemimpin meneladani Tuhan Yesus Kristus yang rela menderita untuk domba-domba tuntunan-Nya (ayat 6; Yoh. 10:11). Sikap seorang pemimpin yang akan menentukan apa yang dilihat dan didengar, bahkan apa yang dipikirkan dan akan dilakukan. Sikap seorang murid harus dimiliki oleh setiap pemimpin Kristen, karena kepemimpinan Kristen sangat ditentukan olehnya. Ia tidak mungkin merubah sikap dari orang-orang yang dipimpinnya, apabila ia sendiri menikmati hidup dengan sikap alamiah yang sudah menjadi bagian hidupnya sejak kecil. Kepemimpinannya gagal apabila ia sendiri menjadi contoh dari orang yang hanya mau mendengar dan mempelajari hal-hal yang ia sukai dan setujui. Kepemimpinannya akan membuahkan "kepasifan", "kepatuhan buta", "rutinisasi", dan "pertengkaran dengan mereka yang berinisiatif" (Susabda, 1990, pp. 54-55).

Salah satu faktor yang menjadikan seseorang menjadi pemimpin adalah pengembangan SDM-nya. Di dalam kekristenan memiliki pijakan yang kuat dalam upaya pengembangan SDM tersebut, yakni penjelmaan Allah menjadi manusia di dalam Tuhan Yesus Kristus. Selama hidup-Nya di dunia, Tuhan Yesus senantiasa melayani, memperlengkapi, memuridkan, memampukan serta mengutus murid-murid-Nya. Mempersiapkan dan mengembangkan seseorang adalah bagian dari misi Tuhan Yesus, misi yang memiliki fokus kepada Kerajaan Allah. Karena itu sangat Alkitabiah dan tepat apabila seorang pemimpin memiliki kesediaan untuk "menjelma", mempersiapkan, menguatkan, memampukan, memperlengkapi dan memberdayakan SDM untuk "menciptakan" seorang pemimpin baru, pemimpin masa depan. Demikian juga membutuhkan suatu proses yang panjang dalam "menciptakan" seorang pemimpin (pengembangan SDM). Di sini dibutuhkan suatu pembentukan yang bersifat holistik; baik rohani, karakter, ketrampilan, daya tahan, dan pengetahuan. Disinilah perlu adanya proses mentoring dan coaching dari pemimpin yang berpengalaman untuk bersedia membagikan hidup, pengalaman, ke- 
trampilan dan pengetahuan sebagai upaya pembentukan SDM, pemimpin yang baru sebagai bagian dari misi Kristen.'

Pada akhirnya seorang pemimpin dapat menjadi pemimpin yang efektif, apabila ia senantiasa mengembangkan dirinya, baik karakter, pengetahuan, keahlian ketrampilan sosial dan kerja serta pengalaman secara kontinyu atau terbiasa. Demikian juga "efektivitas" seorang pemimpin adalah kapasitasnya dalam membangun hubungan dan mengembangkan orang yang dipimpinnya dalam lingkup organisasi. Para bawahan yang diberdayakan dan diberi kesempatan oleh seorang pemimpin merupakan salah satu bukti bahwa pemimpin tersebut adalah efektif (Tomatala, 2005, pp. 255-301).

\section{Kepemimpinan Yang Efisien}

Kepemimpinan yang efisien menyangkut kuantitas dan produksi yang dihasilkan oleh seorang pemimpin dalam kinerjanya secara pribadi bersama dengan para bawahannya. Dimana seorang pemimpinan menerapkan faktor-faktor "efektivitasnya" yaitu: karakter, pengetahuan, keahlian ketrampilan sosial dan kerja serta pengalaman di dalam "efisiensi" yang tinggi dan produktif. Pemimpin yang efisiensi adalah pemimpin yang mengelola waktu, sumber daya manusia serta biaya yang ada padanya secara optimal untuk mencapai hasil yang maksimal, bagi kepentingan dan tujuan bersama (Tomatala, 2005, pp. 301-321). Karena itu, hal-hal yang penting bagi seorang pemimpin Kristen yang efisien adalah:

\section{Visi Mewujudkan Kenyataan Sesuai Harapan}

Visi penting bagi seorang pemimpin sehingga dapat menjalankan kepemimpinannya dengan terarah (Siswanto, 2017, p. 92). Amsal 29:18a menyatakan: "Bila tidak ada visi, manusia kehilangan kendali (liar dan berbuat semaunya sendiri)". Visi diberikan Allah dalam segala bidang untuk mengendalikan umat manusia dari keinginan mengisi bidang-bidang kehidupan semaunya sendiri. Visi diberikan sesuai dengan rencana Allah yang berdaulat dan natur manusia sebagai peta dan gambar-Nya.
Lepas dari kedua hal ini, manusia kehilangan kemanusiaannya. Manusia sangat membutuhkan visi dari Allah, oleh karena hanya berjalan di bawah terang visi-Nya manusia menjadi manusia seutuhnya. Kebenaran ini didukung oleh natur daripada visi itu sendiri, diantaranya: Pertama, visi adalah kebenaran supranatural yang diberikan Allah kepada pribadi tertentu (bukan kepada kelompok) yang terbeban untuk "pekerjaan Allah". Apa yang dapat disebut sebagai "pekerjaan Allah" bukanlah hanya hal-hal yang "secara langsung" berkaitan dengan agama dan keselamatan jiwa semata. Alkitab menyaksikan bahwa hal "menaklukkan dan mengerjakan bumi" (Kej. 1:28 dan Ef. 2:10) dan hal "memikirkan kesejahteraan umat manusia (Mat. 25:31-46 dan Am. 5:22-24) juga termasuk pekerjaan Allah yang dipercayakan kepada manusia. Visi diberikan kepada individu-individu yang "terbeban" untuk hal-hal yang secara iman Kristen disebut sebagai "pekerjaan Allah". Visi tidak sama dengan perencanaan atau ide manusia yang naturnya berubah-ubah dan sangat tergantung pada modal dan kondisi yang ada. Pada saat visi diterima, seringkali kondisinya belum memadai sehingga reaksi negatif dari orang-orang lain bermunculan. Hanya orang yang benar-benar "terbeban" yang akan mengerjakan visi dengan setia. Karena beban untuk "pekerjaan Allah" adalah bagian integral dari natur manusia sebagai peta dan gambarNya. Kedua, biasanya visi diberikan Allah secara nyata meskipun penggenapannya bertahap. Visi melibatkan manusia dalam suatu proses pertumbuhan yang tidak pernah berhenti. Oleh sebab itu, Alkitab menyaksikan bahwa disamping "beban", maka setiap individu tertentu yang mendapat visi dari Allah harus menjawabnya dengan "iman". Karena iman adalah "dasar dari segala sesuatu yang kita harapkan, dan bukti dari segala sesuatu yang tidak kita lihat" (Ibr. 11:1). Memang Alkitab tidak selalu mencatat secara terperinci kesulitan dari pergumulan yang dihadapi hamba-hamba Tuhan dalam melaksanakan panggilan visi Allah. Hanya oleh karena iman, mereka bisa bertahan dan melalui pergumulan-pergumulan itulah mereka bertumbuh, baik me- 
reka sendiri maupun orang-orang yang dipimpinnya. Pertumbuhan itu sendiri adalah manifestasi dari natur manusia sebagai peta dan gambar Allah. Ketiga, biasanya visi memiliki permulaan dan akhirannya, oleh sebab itu ada masanya visi tertentu tidak berlaku lagi, sudah out of date sudah ketinggalan zaman. Sehingga pengulangannya hanya bernilai "program dan rencana" pribadi atau organisasi. Bagaimanapun baiknya, tetap tidak dapat lagi disebut sebagai visi dari Allah.

Manusia boleh saja belajar dari pengalaman orang-orang lain. Namun hanya visi yang membuat manusia memahami akan ketergantungannya kepada Allah. Kerapkali ide-ide yang "dirasakan baru" muncul dalam benak pemimpin, tetapi visi yang sejati dari Allah tidak dihasilkan oleh karena perpaduan dari berbagai pengalaman. Benar seperti yang dikatakan dalam Amsal 29:18b tersebut, karena tanpa visi maka kepemimpinan Kristen hanya akan membuat kekristenan menjadi organisasi dunia. Susabda (1990, pp. 48-50) mengungkapkan bahwa bagaimanapun baiknya tetap tidak menghasilkan "sesuatu yang baru", baik dalam pertumbuhan setiap pribadi orang Kristen maupun dalam pengenalan akan Allah yang hidup (Rat. 3:22-23).

Pada satu sisi, tidak semua orang dipanggil untuk menjadi pemimpin dan menerima visi. Namun pada sisi yang lain, setiap pribadi (manusia) memiliki potensi yang sama untuk menjadi pemimpin, sebagai ciptaan termulia dalam peta dan gambar Allah. Karena itu setiap manusia memiliki potensi yang sama untuk menjadi pemimpin yang visioner. Memang visi bukanlah sesuatu yang datang dengan sendirinya. Namun setiap pribadi dapat menemukan visi dari Allah atas hidupnya maupun kegunaannya bagi sesama. Pada akhirnya apabila kita telah menemukan visi yang sejati dari Allah, maka setiap pribadi yang menerima visi tersebut seyogyanya mengembangkannya untuk tujuan kemuliaan Allah dan kesejahteraan sesama.

Visi adalah suatu penglihatan ke masa yang akan datang. Untuk mencapai suatu visi, maka perlu ditopang oleh nilai-nilai kehidupan para pemimpin dan kelompoknya yang benar. Nilai-nilai seperti kendaraan atau rambu-rambu jalan yang memberi arah sekaligus batas-batas dalam perjalanan kepemimpinan dan tugas-tugas dalam mengaplikasikan visi. Kekristenan memiliki nilai tambah, sebab sumber iman dan praksis kehidupan berasal dari kebenaran Allah dalam firman-Nya. Seorang pemimpin Kristen yang hidup sepadan atau konsisten sesuai dengan firman Allah dalam pikiran, perkataan, perasaan dan tindakannya, maka ia juga memiliki nilainilai hidup yang benar berdasarkan firman Allah. Dengan demikian seluruh aspek kepemimpinannya memiliki arah yang jelas serta panduan yang teguh berdasarkan nilai-nilai kepemimpinan berdasarkan firman Allah.

Visi hanya akan menjadi impian yang abstrak, apabila tidak diejawantahkan dalam misi. Hal-hal yang akan dicapai pada masa yang akan datang hanya merupakan idealisme yang kaku, apabila tidak ada hal-hal yang merupakan tindakan nyata yang harus dikerjakan untuk mewujudkan masa depan. Karena itu, apabila sebuah visi telah dirumuskan, maka harus diikuti dengan misi yang menguraikan hal-hal yang akan dikerjakan (tugas) dan target untuk mewujudkan visi tersebut. Dengan demikian kepemimpinan memiliki tujuan yang jelas, rencana aksi serta realisasi pelaksanaan yang tepat.

\section{Giat Bekerja}

Visi saja tidak akan menghasilkan apa-apa apabila tidak diwujudnyatakan dalam tindakan berpikir, berencana dan bekerja yang disertai kerelaan bersusah payah atau kemauan membanting tulang. Visi yang dibarengi kerja keras merupakan karakteristik tokoh pemimpin dalam sejarah. Musa, misalnya, ia tidak hanya menerima visi mengenai suatu negeri yang berlimpah susu dan madunya; ia harus menghimpun, menyatukan dan mengatur orang Israel sehingga berubah dari suatu gerombolan menjadi suatu bangsa, serta memimpin mereka melintasi gurun yang penuh marabahaya dan kesukaran sebelum mereka sampai ke Tanah Perjanjian tersebut. Sama halnya dengan Nehemia. Setelah ia menerima 
visi mengenai pembangunan kembali Yerusalem, ia mengumpulkan bahan-bahan yang diperlukan untuk membangun tembok serta senjata-senjata untuk melindunginya. Thomas Alva Edison mendefinisikan jenius itu sebagai "1\% inspirasi (ilham) dan 99\% perspirasi (keringat)". Harus ada kombinasi yang seimbang dan terpadu antara visi dan kerja keras, impian dan realitas, minat yang membara dan ketrampilan terapan praktis. Tanpa impian dan visi, usaha kita akan kehilangan arah dan semangat; namun tanpa kerja keras dan proyek-proyek nyata, impian itu akan menguap (Stott, 2000, pp. 466-467).

Dalam diri manusia baik secara individu maupun kelompok serta situasi dan kondisi sosial sangatlah kompleks. Karena itu dibutuhkan seorang pemimpin yang memiliki komitmen rohani yang tebal, suci, militan, trampil dan berhikmat. Hal-hal ini tidak datang dengan sendirinya, namun membutuhkan sebuah proses journey \& formation yang panjang dalam diri seorang pemimpin. Dengan demikian proses pembentukan seorang pemimpin haruslah berwawasan holistik, yang menyentuh segenap aspek hidup pemimpin tersebut, baik pribadinya, rohaninya, kemampuannya, kelenturannya, maupun ketrampilannya.

\section{Pentingnya Perubahan/Inovasi}

Pemimpin yang berinovasi adalah pemimpin yang selalu mencari ide-ide baru untuk mengingkatkan mutu dan hasil. Apabila ia seorang yang mengenal kebenaran firman, maka ia akan menyadari bahwa kerinduannya untuk selalu menemukan hal yang baru, semata-mata lahir dari natur panggilannya sebagai salah satu anggota tubuh Kristus. Ia memang dipanggil untuk memimpin, dan itu hanya dapat terlaksana apabila ia selalu berinovasi. Inovasi merupakan lawan dari status quo. Status quo adalah keadaan "mandeg" yang anehnya kerapkali justru "dinikmati" oleh banyak pemimpin Kristen karena kesuksesan dan kekerabatan yang memberikan kepuasan dan rasa aman (security) tertentu. Begitu status quo sudah memberikan sistem kehidupan yang dinikmati, maka muncullah godaan untuk menying- kirkan inovasi atau semangat yang menghidupi kepemimpinan. Sebenarnya akar kata "kepemimpinan" (leadership) adalah to lead atau memimpin, dan memimpin selalu berarti "adanya perpindahan" meninggalkan status quo menuju sesuatu yang lebih baik. Jiwa "anti-inovasi" kerapkali dimanifestasikan dalam sikap "takut perubahan", "tidak berani mengambil resiko", dan "puas dengan apa yang ada". Ini merupakan faktor dan semangat yang melawan Allah, yang selama manusia masih hidup, selalu membimbing ke arah pertumbuhan yang lebih sempurna. Apa yang menjadi target pertumbuhan setiap individu Kristen tidak pernah akan tercapai apabila pemimpin gereja tidak memiliki jiwa yang berinovasi (Susabda, 1990, p. 51).

\section{Pemimpin Yang Sabar}

Ketekunan merupakan salah satu kualitas kepemimpinan yang paling utama. Dalam setiap upaya mewujudnyatakan visi selalu ada tantangan yang muncul. Segera suatu kegiatan yang baik dimulai, kekuatan-kekuatan yang menentangnya pasti akan muncul. Namun sifat ajaib dari pekerjaan Allah ialah semakin dilawan semakin subur. Mereka yang hanya ikut-ikutan akan mudah menyerah ketika dilanda kesukaran dan bahaya. Tidak demikian dengan seorang pemimpin sejati. Ia memiliki kelenturan mental guna menampung dampak kegagalan dan ketabahan guna mengatasi kelelahan dan kelesuan serta hikmat yang mampu mengubah batu sandungan menjadi batu loncatan. Sebab disamping visi dan kerajinan bekerja, pemimpin yang sejati itu memiliki karunia ketekunan sebagai tambahannya (Stott, 2000, p. 468).

Jangan keliru memahami, ketekunan bukanlah sinonim dari keras kepala. Pemimpin sejati tidak tuli terhadap kritikan. Sebaliknya, ia dengar-dengaran kepada kritikan serta menimbang-nimbangnya, dan tidak jarang mengubah programnya senada dengan kritikan tersebut. Namun keyakinannya yang kuat takkan kunjung goyah karena kritikan. Ia tidak akan menyimpang dari panggilan Allah baginya. Bagaimanapun perlawanan yang muncul sehubung- 
an visi dan misinya itu atau pengorbanan apa pun yang dituntut oleh visi dan misi tersebut, ia takkan mundur, melainkan tetap bertahan dengan tekun.

\section{Metode dan Perilaku Kepemimpinan yang Efisien}

Di atas telah diungkapkan bahwa pemimpin yang efisiensi adalah pemimpin yang mengelola waktu, sumber daya manusia serta biaya yang ada padanya secara optimal untuk mencapai hasil yang maksimal, bagi kepentingan dan tujuan bersama. Karena itu seorang pemimpin yang sejati tidak cukup hanya memiliki hati atau karakter semata, namun juga harus memiliki serangkaian metode dan perilaku/kebiasaan kepemimpinan supaya dapat menjadi pemimpin yang menghasilkan (efisien). Banyak sekali pemimpin yang memiliki kualitas yaitu karakter dan integritas, akan tetapi pada saat menjadi pemimpin formal justru tidak efisien sama sekali karena tidak memiliki metode maupun perilaku kepemimpinan yang baik. Tidak banyak pemimpin yang memiliki kemampuan metode dan perilaku kepemimpinan ini, sebab hal tersebut tidak pernah diajarkan di sekolah-sekolah formal. Oleh sebab itu, setiap institusi perlu terdorong untuk memperhatikan ketrampilan dalam kepemimpinan. Dengan kata lain metode dan perilaku kepemimpinan akan melengkapi para pemimpin yang memiliki karakter kepemimpinan.

Adapun hal-hal yang berkaitan dengan metode kepemimpinan diantaranya: Pertama, para pemimpin perlu memperlengkapi diri dengan manajemen yang benar. Manajemen melibatkan aspekaspek penting seperti: (a) Perencanaan, yaitu upaya yang merangkum seperangkat kegiatan/pekerjaan yang dilakukan berkenan dengan usaha untuk mencapai tujuan organisasi; (b) Pengorganisasian, yaitu proses penataan tugas dan penempatan orang yang tepat bagi setiap tugas pada suatu struktur dalam suatu organisasi; (c) Memimpin, yaitu proses pelaksanaan kerja atau aktualisasi kinerja yang dilakukan oleh pemimpin bersama dan dengan melalui orang lain; serta (d) Mengawasi, yaitu tindakan pemastian kerja, yang memberikan keyakinan serta kepastian kepada pemimpin mengenai apakah pelaksanaan kerja dilaksanakan sesuai dengan perencanaan ataukah tidak (Tomatala, 2006, p. 16-19). Kedua, seorang pemimpin yang efisien sekaligus efektif adalah seorang yang sangat responsif. Artinya dia senantiasa tanggap terhadap setiap persoalan, kebutuhan, harapan, dan impian dari mereka yang dipimpinnya. Selain itu selalu aktif dan proaktif dalam mencari solusi dari setiap masalah maupun tantangan yang dihadapi oleh organisasinya. Pemimpin juga dituntut untuk memperhatikan kebutuhan para anggota, karena mereka akan sulit untuk melayani dan berpartisipasi dalam pelayanan jika mereka tidak dapat memenuhi kebutuhan dasar kehidupan mereka (Objantoro, 2017, p. 126). Ketiga, seorang pemimpin yang efektif adalah seorang pelatih atau pendamping bagi orang-orang yang dipimpinnya (performance coach). Artinya dia memiliki kemampuan untuk menginspirasi, mendorong dan memampukan pengikutnya dalam menyusun peencanaan (termasuk rencana kegiatan, target maupun sasaran, rencana kebutuhan sumber daya dan sebagainya), melakukan kegiatan sehari-hari (monitoring) dan pengendalian serta mengevaluasi kinerja dari orang yang dipimpinnya.

Disamping seorang pemimpin memiliki karakter dan metode kepemimpinan yang baik, seorang pemimpin harus menunjukkan perilaku maupun kebiasaan seorang pemimpin yang efisien, diantaranya: Pertama, pemimpin tidak hanya sekedar memuaskan mereka yang dipimpinnya, namun sungguh-sungguh memiliki kerinduan senantiasa untuk memuaskan Tuhan Yesus Kristus. Artinya hidup dalam perilaku yang sejalan dengan firman Tuhan. Dia memiliki misi untuk senantiasa memuliakan Tuhan dalam setiap apa yang dipikirkan, dikatakan dan dilakukannya. Kedua, pemimpin sejati memusatkan perhatian kepada hal-hal spiritual dibandingkan dengan sekedar kesuksesan duniawi. Baginya kekayaan dan kemakmuran adalah untuk dapat memberi dan menjadi berkat lebih banyak. Apapun yang dilakukan bukan untuk memperoleh penghargaan, namun untuk melayani sesamanya. Dan dia lebih 
mengutamakan relasi atau hubungan yang penuh kasih dan penghargaan, dibandingkan dengan status dan kekuasaan semata. Ketiga, pemimpin sejati senantiasa mau belajar dan bertumbuh dalam berbagai aspek, baik pengetahuan, kesehatan, keuangan, relasi dan sebagainya. Keempat, setiap hari senantiasa menselaraskan (recalibrating) dirinya terhadap komitmen untuk melayani Tuhan dan sesama. Melalui solitude (keheningan/refleksi), prayer (doa) dan scripture (membaca, merenungkan dan melakukan firman Tuhan) (Anonimous, t.t., pp. 2-3). Kelima, pemimpin yang efisien memiliki orientasi pada sasaran. Dalam konteks pendewasaan, orientasi itu adalah kesetiaan untuk melaksanakan mandat yang diberikan oleh Tuhan (Kej. 1:28; 2:15; Mzm. 115:6; Mat. 28:18-20; Mrk. 16:15-16; Luk. 24:47-49; Yoh. 20:21-22; Kis. 1:8). Dia juga menetapkan prioritas untuk menilai segala kegiatan dalam rangka pencapaian sasaran. Keterlibatan dalam pelayanan atau kegiatan yang sejajar dinilai dari sudut komitmen terhadap pencapaian sasaran (Flp. 1:20-22a; 3:7-8) (Lay, 2001, p. 5).

\section{Hubungan Dalam Organisasi Yang Sehat}

Kekristenan memberikan penekanan yang kuat terhadap hubungan yang diwujudkan dalam kasih (agape) dan persekutuan (koinonia). Hal ini telah dilaksanakan oleh Allah terlebih dahulu yang telah mengutus Tuhan Yesus Kristus sebagai Penebus dan Juruselamat yang memulihkan/mendamaikan relasi orang Kristen dengan Dia. Orang Kristen dipanggil oleh Allah dalam satu persekutuan (ekklesia) dalam kasih. Oleh karena itu dalam kepemimpinan dan organisasi Kristen yang sehat, mengembangkan hubungan yang sehat pula merupakan hal sangat mutlak. Hal-hal yang tercakup dalam kaiatannya dengan kesehatan hubungan keorganisasian dalam kepemimpinan Kristen diantaranya adalah:

\section{Prioritas Seorang Pemimpin Kristen}

Seorang pemimpin Kristen adalah hamba Tuhan yang harus memberi pertangung jawaban kepada Kristus, karena itu ia harus menentukan priori- tas-prioritas yang tepat atau hal-hal mana yang harus menjadi "utama atau terdahulu" dalam kehidupan dan pelayanan sebagai hamba Tuhan. Ada hal-hal yang sebenarnya tidak merupakan "prioritas" dalam diri pemimpin Kristen sekalipun tidak harus diabaikan, misalnya pendidikan, karier, kesenangan, hobi, harta kekayaan, kedudukan, dan lain sebagainya. Ada beberapa prinsip, yang seharusnya menjadi prioritas seorang pemimpin Kristen berkaitan dengan membina hubungan: Pertama, keluarga lebih penting daripada pelayanan. Lembaga pertama yang Tuhan buat adalah lembaga pernikahan atau keluarga. Mutu pelayanan kita ditentukan oleh sebuah keluarga! (jika sudah berkeluarga). Kualitas dari pelayanan bukanlah organisasinya, manajemennya ataupun materi. Mutu pelayanan dan gereja ditentukan oleh keluarga! Seseorang yang tidak bisa mengatur/ mengurus keluarga, tidak boleh mengatur rumah Tuhan (2 Tim. 3:5). Kita adalah hamba-hamba yang sombong dan bodoh, apabila pelayanan kita sukses, tetapi keluarga kita terabaikan. Tepat sekali jika ada yang mengatakan bahwa: "Kita harus membawa istri dan anak-anak kita keluar untuk membeli es krim atau mie, daripada menghadiri pertemuan panitia keuangan, paling tidak sekali saja". Kedua, kesetiaan lebih penting daripada persaingan. Sekalipun seorang pemimpin Kristen adalah hamba Tuhan, namun kerapkali oleh karena sifatnya yang berdosa, selalu membanding-bandingkan diri kita dengan orang lain. Kita tidak pernah puas dengan apa yang Tuhan beri dan percayakan pada kita. Karena sering muncul iri hati terhadap potensi dan keberhasilan, muncullah pula persaingan yang sebenarnya tidak Tuhan kehendaki hal itu terjadi. Sebenarnya Tuhan mencari kesetiaan bukan kesuksesan, seperti firmanNya: "Banyak orang menyebut diri baik hati, tetapi orang yang setia, siapakah menemukannya? Barangsiapa setia dalam perkara-perkara kecil, ia setia juga dalam perkara-perkara besar" (Ams. 20:6; Luk. 16:10a). Ketiga, kasih lebih penting dari kemampuan/karunia-karunia/ketrampilan. Paulus menegaskan bahwa ada orang-orang yang memberitakan Injil (melayani) dengan maksud yang tidak baik (dengki 
dan perselisihan), tetapi ada yang melakukannya dengan maksud (motivasi) yang baik yaitu kareka kasih (Flp. 1:15-16). Yang menjadi harapan dari Paulus bagi dirinya sendiri dan jemaat adalah supaya menghasilkan buah kebenaran (Flp. 1:11, 22). Namun buah akan dihasilkan penuh apabila kasih makin melimpah (Flp. 1:9). Kehidupan, keluarga, doa dan pelayanan kita harus di dasari oleh kasih (agape). Kemampuan/karunia-karunia/ketrampilan rohani dan alami yang Tuhan berikan bagi pemimpin Kristen begitu penting, tetapi tidak lebih penting dari kasih.

\section{Peran Pemimpin Kristen Terhadap Yang Dipimpin}

Seorang pemimpin Kristen bukanlah polisi rohani, bukan pula jaksa atau hakim rohani atas mereka yang dipimpin, melainkan penolong bagi mereka yang dipimpin untuk bertumbuh supaya menjadi semakin menjadi dewasa. Kedewasaan seperti yang dimaksudkan dalam Efesus 4:13-14 mencakup tiga aspek penting, yaitu: Pertama, Pengetahuan. Pengetahuan di sini adalah pengetahuan mengenai kebenaran firman Tuhan sehingga orang-orang yang dipimpin mampu membedakan kebenaran (firman Tuhan) dengan ketidakbenaran (ajaran-ajaran palsu). Kemudian dalam kerangka acuan kasih mereka terus bertumbuh "di dalam segala hal ke arah Dia, Kristus". Istilah segala hal di sini mencakup semua aspek dalam interaksi mereka dengan orang-orang lain sehingga hidup mereka sebagai orang-orang yang telah dipanggil "berpadanan dengan panggilan itu" (Ef. 4:1; 1 Pet. 1:14-16). Kedua, Sikap hati yang benar dan mantap. Kedewasaan penuh menyebabkan seseorang tidak mudah dipengaruhi dan diombang-ambingkan (Ef. 4:13-14). Sikap hati yang benar dan mantap seperti ini bersumber pada pengetahuan yang benar mengenai Kristus. Orang-orang yang demikian memiliki kerelaan dan kesediaan untuk melayani. Ketiga, Ketrampilan untuk melayani. Dalam Efesus 4:12 menegaskan, "untuk memperlengkapi orang-orang kudus bagi pekerjaan pelayanan, bagi pembangunan tubuh Kristus". Kata kerja bahasa Yunani yang digunakan dalam frase "memperleng- kapi orang-orang kudus" sama dengan yang dipakai dalam Injil Matius, surat-surat Paulus, dan surat Ibrani, yaitu katartizo yang berarti antara lain: membereskan jala (Mat. 4:21), cakap mengajar orang lain (2 Tim. 2:2), memperlengkapi dengan segala yang baik (Ibr. 13:21). Semua kata kerja dalam frase-frase ini berhubungan dengan ketrampilan. Ketrampilan atas dasar pengetahuan yang benar menyebabkan seseorang mampu untuk melayani (Lay, 2001, p. 4).

Demi mewujudkan hubungan yang berkaitan dengan sehatnya sebuah organisasi Kristen, maka seorang pemimpin Kristen harus menolong para pengikutnya dengan hal-hal sebagai berikut: (a) Memberikan visi dan aktivitas-aktivitas yang mungkin untuk dilakukan; (b) Memberi semangat dengan menonjolkan segi-segi yang terbaik dari masing-masing pengikut; (c) Mendorong mereka yang dipimpin untuk menggunakan kemampuan-kemampuan mereka dengan cara memberikan kesempatan kepada mereka untuk melayani kelompok; (d) Mendengar secara aktif dengan memusatkan perhatian pada para pengikut yang sedang berbicara sambil mengajukan pertanyaan-pertanyaan yang memperjelas isi pembicaraan; (e) Bersikap terbuka terhadap usul-usul atau gagasan dari mereka yang dipimpin; (f) Membangun keterbukaan, menciptakan saling pengertian satu terhadap yang lain; (g) Menolong anggota kelompok untuk mengungkapkan apa yang mereka pikirkan dan rasakan dengan cara menerima semua yang mereka nyatakan sebagai tanggapan yang benar dan sungguh-sungguh; (h) Peka menilai hubungan antar orang-orang yang dipimpin; (i) Membangun keharmonisan dan kesepakatan, menyelesaikan masalah antar pribadi, menyelesaikan konflik-konflik dan ketidaksesuaian pendapat di antara anggota dengan cara menganalisa perbedaan-perbedaan tersebut secara obyektif dan berusaha mencari titik temu; (j) Meningkatkan rasa kesatuan/kekompakan kelompok dengan memberikan kesempatan untuk bercakapcakap dengan terbuka; (k) Membangun rasa percaya diri mereka yang dipimpin dengan merekomendasi anggota untuk melayani. Setiap anggota pada umumnya memiliki kemampuan lebih dari satu pe- 
ran tersebut di atas; (1) Sebuah organisasi yang sehat dan yang paling berhasil adalah organisasi yang dapat mengembangkan bakat kepemimpinan kepada anggota-anggotanya.

\section{Pemimpin Kristen dan Team Pelayanannya}

Kepemimpinan sebuah pelayanan pada umumnya berkembang dari seorang pemimpin karismatis kepada kepemimpinan team. Demikian halnya dalam dunia manajemen, di masa lampau yang disebut manajer efektif adalah manajer yang mengetahui segalanya, tegas dalam mengambil keputusan sendiri. Namun di masa kini dan masa depan, manajer yang efektif adalah bila ia bersama-sama manajer yang lainnya dapat menyatukan berbagai pengetahuannya untuk memperoleh suatu solusi bagi permasalahan yang dihadapi.

Tuhan Yesus Kristus selama hidupnya menjadi contoh yang agung bagaimana Ia melatih dan memperlengkapi para murid untuk melayani dalam team. Ia selalu mengutus para murid berdua, Ia dalam hal-hal yang sangat penting selalu meminta penyertaan dari Yohanes, Yakobus dan Petrus. Dalam kasus mujizat 5 roti dan 2 ikan, Ia mengajak murid-murid untuk berdiskusi dan mengamati permasalahan yang ada serta kemungkinan solusinya. Dalam Perjanjian Lama, dengan jelas dikatakan bagaimana Musa diberi nasihat oleh Yitro untuk mengangkat pemimpin-pemimpin yang cakap supaya bisa memimpin bersama Musa secara team leadership. Adapun manfaat dari kerja team adalah: (a) Kualitas kerja semakin baik; (b) Hasil pelayanan semakin berlipatganda, karena terjadinya sinergi; (c) Tidak bergantung hanya kepada satu orang saja, memungkinkan proses kaderisasi berjalan dengan baik; dan (d) Membangun sikap rendah hati dan saling menghargai.

Kerja team pada akhirnya akan membawa pada pengambilan keputusan team. Maka istilah penting yang perlu dipahami dalam hal ini adalah konsensus, yang berarti kita bisa menerima sesuatu sebagai solusi suatu permasalahan dan kita semua setuju untuk melakukan apa saja sesuai yang diisyaratkan dalam hal yang telah diterima dan disepakati sebagai solusi tersebut. Konsensus tercapai apabila: (a) Anggota team telah didengar; (b) Anggota team berterus terang dan jujur; (c) Pandangan telah didengar; (d) Informasi telah disebarkan; (e) Anggota "mendapatkan" keputusan; dan (f) Anggota bisa "mendukung" keputusan yang diambil. Adapun kiat-kiat dalam memperoleh sebuah konsensus adalah: (a) Jujur dan terus teranglah apabila mengungkapkan ide atau gagasan; (b) Hindari menghakimi setiap gagasan dan ciptakan rasa aman; (c) Bersedialah kompromi dan fleksibel untuk halhal tertentu; (d) Ujilah keputusan dan masalah secara sistematis; (e) Sejak awal sepakati masalah yang akan dibahas dan tujuan yang hendak dicapai; (f) Pastikan setiap anggota team mendapat informasi yang sama; dan (g) Beri waktu yang cukup untuk mencapai konsensus, namun jangan terlampau lama (Arthanto, 2004, pp. 10-11).

Dengan demikian membangun sebuah team yang kuat tidaklah terlepas dengan seni untuk memberikan kesempatan berkembang/bertumbuh bagi bakat, keahlian, kemampuan, gagasan/ide dan pengalaman dari semua anggota team secara penuh. Karena itu salah satu tugas utama kepemimpinan adalah menyediakan peluang yang kondusif supaya setiap pribadi bertumbuh ke arah kedewasaan penuh (Ef. 4:12-16). Dalam relasi kedewasaan penuh, baik si pemimpin maupun orang-orang yang dipimpinnya terdapat apresiasi bukan saja terhadap sumbangsih dan talenta seseorang tetapi terutama terhadap orang itu sebagai pribadi (Lay, 2001, p. 5). Hal ini akan mewujudkan hubungan yang sehat dalam sebuah organisasi yang sehat pula pada sebuah kepemimpinan Kristen.

\section{Mewujudkan dan Mengembangkan Kerjasama}

Pelayanan dalam hubungan yang saling bertumbuh dan mendewasakan antara pemimpin dan yang dipimpin akan membentuk kerjasama (sinergi). Istilah sinergi berasal dari bahasa Yunani: sun artinya bersama-sama dan ergon artinya kerja. Jadi sinergi dapat didefinisikan sebagai "kerjasama anta- 
ra orang-orang yang sehati, sehingga hasil keseluruhan yang dicapai lebih besar dari pada hasil yang dicapai apabila masing-masing bekerja sendiri" (Lay, 2001, p. 6).

Alkitab menyaksikan bahwa kepemimpinan Kristen atau kepemimpinan rohani hanyalah "salah satu karunia" di tengah karunia-karunia yang berbeda-beda dalam kesatuan tubuh Kristus (Rm. 12; 1 Kor. 12; Ef. 4). Dalam konteks kesatuan tubuh Kristus, karunia kepemimpinan bukanlah karunia terbesar yang diberikan kepada mereka yang lebih penting daripada anggota tubuh yang lain (1 Kor. 12:1426). Kepentingannya hanyalah kepentingan dalam keunikan peranannya sebagai pemimpin, sama halnya dengan kepentingan dari setiap anggota tubuh yang lain, yang juga terletak pada keunikan peranan masing-masing. Dalam konteks kesatuan tubuh Kristus, setiap anggota penting dan setiap anggota memiliki keunikan peranannya dalam membangun tubuh Kristus. Oleh sebab itu, kerjasama dengan setiap anggota tubuh Kristus (yang tentunya berbeda watak/karakter, bakat, dan panggilan) bukanlah suatu pemilihan melainkan suatu "syarat mutlak dan keharusan".

Hidup ini penuh dengan tantangan-tantangan dan tugas-tugas kehidupan yang tidak mungkin dilakukan sendiri. Kerjasama secara Alkitabiah bukanlah sekedar membagi pekerjaan demi keringanan. Namun suatu manifestasi dari natur manusia sebagai peta dan gambar Allah, makhluk sosial, yang pertumbuhannya memang hanya terjadi melalui proses "penyesuaian diri dan saling mengisi kekurangan dengan sesamanya". Kerjasama yang sejati adalah suatu proses yang sangat menyakitkan, karena harus diwujudkan melalui penyangkalan diri sendiri secara terus menerus.

Kepemimpinan Kristen hanya merupakan suatu sarana yang kosong apabila berada di tangan pemimpin yang tidak mengenal kerjasama yang sejati. Ketakutan (phobia) atas kritik dan perbedaan pendapat, semangat pelayanan yang didasarkan atas jiwa kompetisi, kerjasama tanpa konflik yang jujur adalah tiga dari tanda-tanda utama dari kerjsama yang palsu dan mati. Kerjasama yang tidak menghasilkan pertumbuhan, baik dalam diri si pemimpin maupun mereka yang dipimpinnya (Susabda, 1990, pp. 47-48).

Dalam kerjasama seperti yang diuraikan di atas, semua fungsionaris dalam sebuah lembaga/ organisasi atau jemaat memberdayakan fungsinya dalam saling membantu, saling menjaga integritas dan saling mengasihi. Dengan kata lain pada tahap ini, kasih (agape) dioperasionalkan secara maksimal (Ef. 4:2-6). Biasanya, operasionalisasi kasih ini dirumuskan dalam semboyan Asih-Asah-Asuh (Lay, 2001, p. 5).

\section{KESIMPULAN}

Dalam perspektif Kristen, pemimpin adalah seorang yang dipanggil, dipersiapkan dan diberi kapasitas oleh Allah untuk melaksanakan misi-Nya. Pemimpin yang baik ditandai dengan karakter dan komitmen yang tebal, kecerdasan, ketrampilan dan kemampuannya. Pemimpin yang baik juga dapat dipercaya, sebab dia menerima kepercayaan dari Allah dan manusia. Pada akhirnya menjadi seorang pemimpin merupakan dedikasi terhadap pengikut di dalam sikap hidup dan karyanya.

Seorang pemimpin adalah figur panutan dari yang dipimpin. Segala sepak terjang seorang pemimpin pada umumnya ditiru oleh yang dipimpin. Maka seorang pemimpin Kristen sangat memerlukan energi rohani dan pengembangan kapasitas yang memadai. Oleh sebab itu, seorang pemimpin Kristen harus terus menerus bertumbuh di dalam hubungan dengan Kristus, serius dalam hubungannya dengan Allah serta senantiasa mengembangkan hubungan dengan mereka yang dipimpinnya. Allah yang memiliki inisiatif dalam memilih para pemimpin-pemimpin dalam pekerjaan-Nya. Dia juga memberikan kapasitas bagi para pemimpin dalam menjalankan tugastugas yang dipercayakan-Nya. Seorang pemimpin yang baik tidak boleh mengandalkan dirinya sendiri, tetapi harus memiliki ketergantungan kepada Allah dalam menjalankan tugas-tugas dari Tuhan yang kerapkali penuh dengan tantangan dan kesulitan. Be- 
ban dan tanggungjawab yang berat selalu berada di pundak seorang pemimpin. Ia harus senantiasa mengandalkan Tuhan serta memohon kekuatan dan kemampuan dari-Nya dalam melaksanakan tugas-tugas yang berat tersebut. Disamping itu seorang pemimpin yang menerima kapasitas dari Allah perlu memakai kapasitas tersebut dalam menyusun rencana kerja dan melaksanakan dengan pertolongan Tuhan. Dengan kemampuan dari Tuhan, maka seorang pemimpin akan memiliki motivasi dan sikap yang selalu didorong untuk maju dan pantang menyerah. Dia juga memotivasi para bawahannya untuk memiliki sikap dan perilaku yang rindu untuk meraih keberhasilan dalam pertolongan Tuhan. Karena itu disiplin kehidupan doa para pemimpin sangat mutlak.

Seorang pemimpin Kristen senantiasa dituntut untuk memiliki prioritas untuk menyediakan waktu yang cukup secara teratur untuk mendalami, menghayati dan menerapkan firman Tuhan, memiliki penuntutan diri secara terus menerus untuk mem-

\section{DAFTAR RUJUKAN}

Anonimous. t.t. Kepemimpinan yang Melayani. Makalah yang tidak diterbitkan.

Arthanto, H.G. 2002. Pemimpin dan Karakter. Makalah Pelatihan Pengembangan Mentor PESAT, Salatiga: Yayasan PESAT.

Arthanto, H.G. 2004. Kepemimpinan. Makalah Kuliah pada Program Holistic Child Development, Salatiga: STT Terpadu PESAT.

Djadi, J. 2009. “Kepemimpinan Kristen Yang Efektif". Jurnal Jaffray, 7 (1): 16-30.

Lay, A. 2001. Kepemimpinan yang Efektif dalam Pelayanan. Makalah Persekutuan dan Pelatihan Pelayanan PESAT, Bandungan: Yayasan PESAT.

Objantoro, E. 2017. "The Contextual Church Leadership". Dalam I P.A. Darmawan (Ed.), Melaksanakan Amanat Agung di Abad 21 (hlm. 123-134). Ungaran: STT Simpson.

Siswanto, K. 2017. "Pemimpin Sukses dari Perspektif Kepemimpinan Kristen”. Dalam I P.A. bangun dirinya supaya semakin memiliki kekuatan rohani, mental, intelektual dan jasmani. Pada akhirnya seorang pemimpin Kristen harus menyediakan waktu yang cukup untuk membagi hidupnya bagi mereka yang dipimpin.

Pemimpin Kristen bukanlah superman rohani. Ia tidak lebih dari seorang yang sedang dan akan terus menerus menjadikan dirinya sendiri murid Kristus. Dan sementara itu, ia juga dituntut untuk menolong mereka yang dipimpinnya menjadi murid Kristus sebagaimana yang sedang ia jalani. Dengan demikian seorang pemimpin Kristen adalah seorang yang sedang belajar dan sekaligus mengajar. Ia adalah seorang yang sedang melatih dirinya sendiri dan sementara itu juga melatih orang lain. Ia adalah seorang yang sedang terus menerus bertumbuh sekaligus menolong orang lain untuk dapat bertumbuh. Segala sesuatu yang sedang pemimpin Kristen pelajari dan latih akan membuat dia semakin paham dan trampil apabila hal itu dibagikan kembali kepada orang lain.

Darmawan (Ed.), Melaksanakan Amanat Agung di Abad 21 (hlm. 91-102). Ungaran: STT Simpson.

Stott, J. 2000. Isu-isu Global Menantang Kepemimpinan Kristiani. Jakarta: Yayasan Bina Kasih/OMF.

Susabda, Y. 1990. "Tantangan dalam Kepemimpinan dan Manajemen Gereja", dalam $M e$ nuju Tahun 2000: Tantangan Gereja di Indonesia. Bandung: Pusat Literatur Euangeliom GII Hok Im Tong.

Tomatala, Y. 1996. Pemimpin Yang Handal. Jakarta: YT Leadership Foundation/IFTK Jaffray.

Tomatala, Y. 2002. Kepemimpinan Kristen. Jakarta: YT Leadership Foundation/IFTK Jaffray.

Tomatala, Y. 2005. Anda Juga Bisa Menjadi Pemimpin Visioner. Jakarta: Media Penerbit Kristen YT Leadership Foundation. 
Tomatala, Y. 2005. Kepemimpinan Yang Dinamis. Jakarta: YT Leadership Foundation/IFTK Jaffray dan Penerbit Gandum Mas Malang.
Tomatala, Y. 2006. Kepemimpinan, Manajemen dan Administrasi Gereja. Makalah Kuliah di ICDS Jakarta, Jakarta: ICDS. 